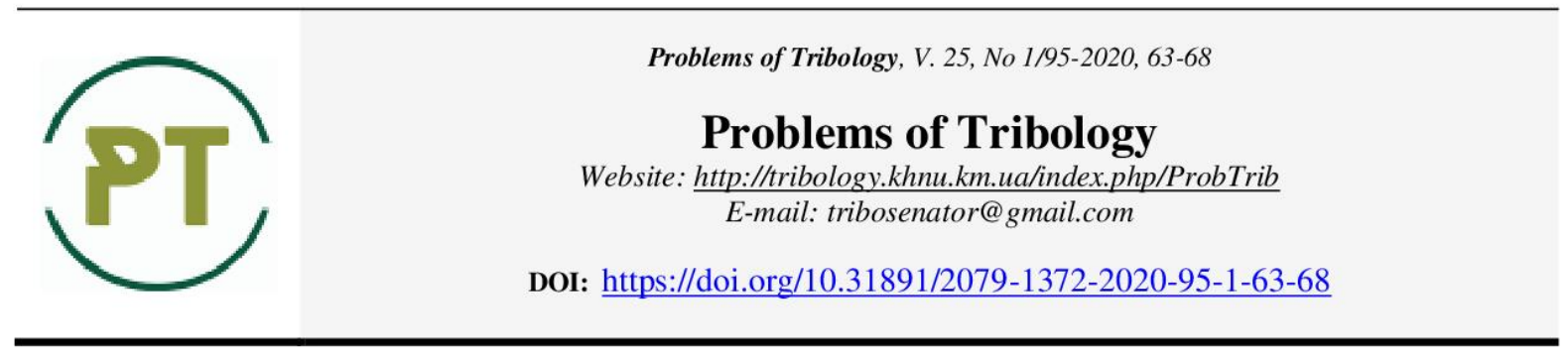

\title{
Quantum-mechanical approaches in evaluating the contact interaction of tribosystems
}

\author{
Yu. Zaspa ${ }^{1}$, A. Dykha ${ }^{1^{*}}$ \\ ${ }^{1}$ Khmelnitskyi National University, Ukraine \\ *E-mail: tribosenator@gmail.com
}

\begin{abstract}
The physical mechanisms of the formation and transformation of corpuscular-vortex-wave thermal complexes in contact tribosystems based on the quantum-mechanical exchange interaction in ensembles of identical quasiparticles are considered. The presence of contact discontinuity of two thermostats with different signs of absolute temperature determines the generation of pairs of quasiparticle perturbations stabilized along the wavelength in cooperation with photons of stimulated thermal radiation, and also in frequency in interaction with phonons. Internal instability and collapse processes in such a system of perturbations lead to the formation of defects in the material of the tribocouple and are the cause of emergency friction conditions. Specific technical examples of thermal complex generation during fretting, sliding and rolling friction, and cutting are given. A corpuscular-vortex-wave mechanism of selective transfer and hydrogen wear in tribosystems is proposed.
\end{abstract} collapse.

Key words: contact tribodynamics, corpuscular-eddy-wave thermocomplex, exchange interaction,

\section{Introduction}

The dynamic contact of deformable solids is a source of a wide range of disturbances leading to catastrophic consequences. [1-4]. The presence of contact discontinuities in the regimes of dry and boundary friction, the temporal and spatial discreteness of contacting limit the possibilities of the methods of continuum mechanics and classical field theory in describing such modes. In this case, it is advisable to use ideas and methods developed in quantum field theory, as well as in the theory of turbulence [5-7]. Introduction

One of the most effective methods of this type is the description of disturbances in the form of a quantum ensemble of quasiparticles participating in a specific exchange interaction, which is absent in classical mechanics $[5,6]$. Introduction

This interaction, which occurs against the background of ordinary processes of an electromagnetic nature, determines the catastrophic modes of contact-induced flutter and buffet. The indicated modes are also characteristic of hydro and aerodynamic systems under conditions of flow continuity rupture. At the same time, a useful effect associated with the exchange interaction is the well-known effect of wearlessness (selective transfer) $[8,9]$, the theory of which needs to be substantially refined.

Here, the hydrogen depreciation is a controversial mode $[8,9]$, which has been described up to now without taking into account the exchange interaction and vortex-wave transfer in tribosystems. The specificity of contact friction also manifests itself in sharp temperature gradients, which leads to the formation of corpuscularvortex-wave thermal complexes [10] participating in the exchange interaction. Cooperative processes in the system of such thermal complexes are essentially the main source of contact-induced disturbances. The objective of this work is the formation of a physical model of contact generation of disturbances in tribosystems, taking into account the exchange interaction and collapse of the particle-vortex-thermal complexes.

\section{Estimated ratios}


Consider contact-induced disturbances in a tribosystem in the form of an ensemble of quasiparticles with the following characteristics:

$$
E= \pm \vec{p} \vec{v}, \quad \vec{p}=\hbar \vec{k}
$$

where $E, \vec{p}, \vec{v}, \vec{k}$ are the accordingly, the energy, momentum, velocity, and wave vector of perturbations, $\hbar$ Planck's constant. Substituting (2) in (1), we obtain:

$$
E= \pm \hbar \vec{k} \vec{v}=\hbar \omega, \omega= \pm \vec{k} \vec{v}
$$

where $\omega$ is cyclic disturbance frequency. In this case, the group speed of the latter is defined as:

$$
\vec{V}_{q r}=\frac{\partial E}{\partial \vec{p}}=\frac{\partial \omega}{\partial \vec{k}}= \pm \vec{V}
$$

We introduce the particle-wave mass of disturbance quanta in the usual way:

$$
\vec{p}=m \vec{V}=\hbar \vec{k}
$$

As a result, equivalent relations for energy follow from (1-6):

$$
E=\hbar \omega= \pm m(\vec{v})^{2}= \pm \frac{\hbar^{2}}{m}(\vec{k})^{2}
$$

The signs \pm in all the above expressions correspond to two possible directions of time. Of these two possibilities, the first (plus sign) is usually selected, which corresponds to the positivity of the absolute temperature $T$ and the non-negative increase in entropy $\Delta S[6]$ :

$$
T\rangle 0, \Delta S \geq 0 .
$$

Here we take into account the second possibility (minus sign in (1-7)):

$$
T>0, \Delta S \leq 0 \text {. }
$$

The possibility of negative absolute temperatures in the system of quasiparticles was allowed earlier [6]. In this case, when two thermostats contact with different signs of absolute temperature, heat was transferred towards positive temperatures [6]. Here, conditions $(10,11)$ are not only admissible, but necessary and equal with $(8,9)$. It is as a result of the contact of two thermostats with different signs of absolute temperature that the disturbances are amplified. In this context, we introduce a pair of perturbations with total energy $\Delta E$ (taking into account the signs in (1)):

$$
E=\vec{p} \vec{v}-\vec{p}^{\prime} \vec{v}^{\prime}
$$

where the dashes denote disturbances that develop in time opposite to the unshaded ones. The module of the total energy of pairs is limited from below by the basic principle of quantum mechanics - the principle of uncertainty:

$$
|\Delta E| \geq \hbar /|\Delta t|,
$$

where $\Delta t$ is the finite time of the action of the disturbances forming the pair. On the other hand, due to the same principle of uncertainty, energy $\Delta E$ can be considered as the energy of self-perturbation, and relation (12) as a condition of the energy balance in the triad of perturbations. To it should be added the law of conservation of momentum in such a triad:

$$
\vec{p}=\vec{p}-\vec{p}^{\prime}, \Delta \vec{k}=\vec{k}-\vec{k}^{\prime} .
$$


Here we can mention the widespread use of expressions of the form (14-15) in the calculations of nonlinear energy and momentum transfer by triads of wave disturbances in theories of quasi two-dimensional turbulence [7]. The most famous result of these calculations is the inverse energy cascade (towards large spatial scales), opposite the direct cascade of ordinary three-dimensional turbulence [7].

Referring the triples of perturbations of the form (12-15) to bosons, we use the Bose-Einstein statistics here, taking into account the possibility of exchange interaction in the perturbation ensemble:

$$
\left\langle n_{E}\right\rangle=\frac{1}{e^{\frac{E}{k T}}-1},
$$

where $\left\langle n_{E}\right\rangle$ is the average number of quasiparticles in a quantum state with energy $E, k$ is the Boltzmann constant.

In view of the variable number of perturbations, the chemical potential in (16) is set equal to zero [5, 6]. The possibility of different signs of absolute temperature (corresponding to signs of energy) in the exponent in (16) ensures the positiveness of the average fill numbers $\left\langle n_{E}\right\rangle$ in all cases.

As applied to tribodynamics, we note that the perturbation energies $E$ lie in the acoustic range, while the average thermal energy $k T$ is many orders of magnitude higher. Expanding the exponent in (16) in a row and discarding the small terms, we obtain a simpler relation for the average fill numbers:

$$
\left\langle n_{E}\right\rangle \approx \frac{k T}{E},\langle E\rangle=E \cdot\left\langle n_{E}\right\rangle \approx k T
$$

Here $\langle E\rangle$ is the average energy of the entire ensemble of identical quasiparticles in a certain quantum state. The approximate equality of this energy to the average thermal energy determines the possibility of efficient energy exchange between the perturbation ensemble and the thermostat. As will be shown below, this exchange is carried out using photons of stimulated thermal radiation. In view of the above remark, the conditions are met:

$$
E\left\langle\left\langle k T,\left\langle n_{E}\right\rangle\right\rangle\right\rangle 1,
$$

which determines the high efficiency of the exchange interaction in this system of perturbations.

For bosons, as is known $[5,6]$, it has the character of attraction, which, as will be shown in real examples, can significantly exceed the repulsive contact forces of electromagnetic origin.

The potential for exchange interaction can be revealed only under conditions of coherence, which is ensured by stabilization along the wavelength of disturbances (in cooperation with photons of stimulated thermal radiation), and also by frequency in interaction with phonons. Both obey statistics (16) and have basic relationships similar to (1-2). The functioning of tribosystems in the mode of a coherent generator of acoustic radiation (phaser) was considered in general terms earlier [11]. Here, significant refinements should be made to the physical mechanisms of such processes of generation of perturbations. First of all, with respect to the nonequilibrium medium itself, as well as the structure of the composite resonator.

Statistics (16) deseribes the equilibrium states of an ensemble of quantum objects. The unusual situation in this case is that in the presence of two (rather than one) thermostats with different signs of absolute temperature, forced amplification of pairs of perturbations of the form (12) is possible even with the equilibrium distribution of quasiparticles in each subsystem separately. The role of the negative temperature, so familiar in creating an inverse population in quantum electronics systems [5], is assigned here to the aforementioned temperature difference between the two thermostats.

Simultaneous stabilization in both wavelength and frequency determines the multilevel structure of the resonator of the contact perturbation generator. The main role here is assigned to the mesoscopic spherical resonator, which is formed as a part of the corpuscular-eddy-wave thermal complexes. The radius of such a resonator is determined based on the relation [10]:

$$
\lambda=2 \bar{n} r=\frac{2 \bar{n}}{\tilde{R}}=\frac{h}{m V}=\frac{b}{T}=\frac{c h}{4,965 R T} .
$$


Here $\lambda, \tilde{R}, v$ is the wavelength, wave number and modulus of the velocity of quasiparticles, $b$ is the Wien constant, is the speed of light in vacuum, $h=2 \bar{n} \hbar$ is Planck's constant, 4.965 is the root of the transcendental equation for finding the Wien constant [6].

Relation (21) reflects the stabilization of the wavelength of the thermal complex (and, accordingly, the radius of the resonator) over the extremum in the spectrum of equilibrium thermal radiation corresponding to the temperature. Combining the above expressions, we obtain additional relations for the cyclic frequency and velocity of the particle-vortex-wave thermal complexes:

$$
\omega= \pm \frac{(4,965 R T)}{\hbar m c^{2}}, \frac{v}{c}=\frac{4,965 R T}{m c^{2}} .
$$

These expressions describe the right (high-frequency) part of the triad of perturbations (12). The lowfrequency part of these triads with energy $\Delta E$ competes with two high-frequency components in view of the sharp increase in the role of stimulated thermal radiation with respect to spontaneous with increasing wavelength $[5,6]$. This causes the formation of low-frequency clusters of contact-induced disturbances in the infrasonic part of the acoustic spectrum. The macroscopic resonator of the contact perturbation generator is formed by the whole complex of feedbacks in the tribosystem [11]. Here, both high-frequency stabilization on the natural forms of vibrations of the elements of the tribosystem is possible, and low-frequency stabilization on the angular forms of rotating parts and weakened forms of vibration of the drive.

\section{Collapse of the particle-vortex-wave thermal complexes}

In addition to the pseudo-equilibrium perturbation generation scheme considered above, another scheme is also possible - with collapse energy pumping. It is she who underlies emergency and catastrophic regimes. Propagating in the material of contact and contact layers, the above-mentioned particle-vortex-wave thermal complexes can attach to themselves a material mass $M$ enclosed in the volume of a spherical resonator and determined by the ratio:

$$
M v^{2} / 2=k T \text {. }
$$

In this case, from the above expressions, there follows a restriction on the density of the attached substance (for the high-frequency component of perturbations):

$$
\rho=\frac{59,58}{c h^{3}}(\pi m k T)^{2}
$$

Owing to contact discontinuity, the effective density of the attached substance can dynamically vary and automatically adjust to condition (25). From (1-25) it also follows:

$$
\frac{M c^{2}}{m c^{2}}=\frac{2}{(4,965)^{2}} \frac{m c^{2}}{k T}=\frac{2}{4,965} \frac{c}{v}
$$

In the case of the addition of all energy $\left.\left.M c^{2}\right\rangle\right\rangle E$ (or a significant part of it $\varepsilon M c^{2}$ ) in (16), the average filling numbers are zeroed and the thermocomplex collapses (breaks down). The correlated destruction of many thermocomplexes leads to colossal, by tribological standards, energy release.

For example, a micron-sized spherical resonator with attached condensed matter of ordinary densities contains an energy of $\left.M c^{2}\right\rangle 10^{2} \mathrm{~J}$.

At that time, according to the estimates of [1], only $\sim 10^{-4} \mathrm{~J}$ is needed for plastic deformation of a substance volume with a side of $\sim 0.1 \mathrm{~mm}$. Even an insignificant value of the attachment coefficient $\varepsilon\langle\langle 1$ can provide negative friction effects (at local stages of time) during the most normal functioning of tribosystems, which has no rational explanation in the framework of generally accepted approaches [11-13].

\section{Conclusion}

The physical mechanisms of the formation and transformation of corpuscular-eddy-wave thermal complexes in contact tribosystems are considered. The presence of contact rupture of two thermostats with different signs of absolute temperature determines the generation of pairs of quasiparticle disturbances. Internal 
instability and collapse processes in such a system of perturbations lead to defect formation in the material of the tribocouple and underlie emergency friction conditions.

\section{Refrences}

1. Свириденок А.И., Мышкин Н.К., Калмыкова Т.Ф., Холодилов О.В. Акустические и электрические методы в триботехнике / Под ред. В.А. Белого - Мн.: Наука и техника. - 1987

2. Akay A. Acoustics of friction // J. Acoust. Soc. Am. - 2002 (111), №4, 1525-1548.

3. Сергиенко В.П., Бухаров С.Н., Купреев А.В. Вибрация и шум в тормозных системах мобильных машин. Часть 1. Экспериментальные методы исследования (обзор) // Трение и износ. - 2008 (29), №3, 306-314.

4. Сергиенко В.П., Бухаров С.Н. Вибрация и шум в тормозных системах мобильных машин. Часть 2. Теоретические методы исследования // Трение и износ. - 2009 (30), №3, 296-310.

5. Физика микромира. Маленькая энциклопедия / Под ред. Д.В. Ширкова. - М.: Сов. энц. - 1980.

6. Ландау Л.Д., Лифшиц Е.М. Статистическая физика. - М.: Наука. - 1975.

7. Данилов С.Д., Гурарий Д. Квазидвумерная турбулентность // УФН. - 2000 (170), №9, 922-968.

8. Справочник по триботехнике. В 3-х т. Т. 1. Теоретические основы / Под ред. М. Хебды и АВ. Чичинадзе. - М.: Машиностроение. - 1989.

9. Гаркунов Д.Н. Триботехника. - М.: Машиностроение. - 1989.

10. Zaspa Yu.P. Corposcular-vortex-wave thermocomplexes (triones) in heterogenic systems: technical, cosmic, pseudoelementary, biological // Herald of Khmelnytskyi nat. univ. - 2019 (275), №4, $227-241$.

11. Заспа Ю. П. Когерентная трибодинамика // Трение и износ. - 2012 (33), №6, 656-674.

12.Заспа Ю.П. Внутренний синтез движений и динамические характеристики внешнего трения // Трение износ. - 2011 (32), №3, 233-247.

13. Заспа Ю.П. Автоволновое трение и неравновесная динамическая саморегуляция трибосистемы // Трение и износ. - 2012 (33), №5, 537-549. 
Заспа Ю., Диха О. Квантово-механічні підходи в оцінці контактної взаємодії трибосистем

Розглянуті фізичні механізми утворення i трансформації корпускулярно-віхрехвильових термокомплексів в контактних трибосистемах, засновані на квантово-механічній обмінній взаємодії в ансамблях тотожних квазічасточок. Наявність контактного розриву двох термостатів з різними знаками абсолютної температури визначає генерацію пар квазічасточок збурень, стабілізованих по довжині хвилі в кооперації з фотонами вимушеного теплового випромінювання, а також за частотою у взаємодії 3 фононами. Внутрішня нестійкість и колапсні процеси в такій системі збурень ведуть до дефекту утворення в матеріалі трибопари і лежать в основі аварійних режимів тертя. Наведені конкретні технічні приклади генерації корпскулярно-хвильових термокомплексів при фретинзі, терті ковзання і коченні, piзанні. Запропонований корпускулярно-хвильовий механізм вибіркового переносу i водневого зношування в трибо системах.

Ключові слова: контактна трибодинаміка, корпускулярно-вихрехвильовий термоломплекс, обмінна взаємодія, колапс.инні рештки 